\title{
The Striatal and Extrastriatal D2/D3 Receptor-Binding Profile of Clozapine in Patients with Schizophrenia
}

\author{
Gerhard Gründer*, 1,2, Christian Landvogt ${ }^{3}$, Ingo Vernaleken ${ }^{1,2}$, Hans-Georg Buchholz ${ }^{3}$, Jasmin Ondracek', \\ Thomas Siessmeier ${ }^{3}$, Sebastian Härtter ${ }^{1}$, Mathias Schreckenberger ${ }^{3}$, Peter Stoeter ${ }^{4}$, Christoph Hiemke', \\ Frank Rösch ${ }^{5}$, Dean F Wong, ${ }^{6,7}$ and Peter Bartenstein ${ }^{3}$ \\ 'Department of Psychiatry, University of Mainz, Mainz, Germany; '2Department of Psychiatry and Psychotherapy, RWTH Aachen University, \\ Aachen, Germany; ${ }^{3}$ Department of Nuclear Medicine, University of Mainz, Mainz, Germany; ${ }^{4}$ Institute of Neuroradiology, University of Mainz, \\ Mainz, Germany; ${ }^{5}$ Institute for Nuclear Chemistry, University of Mainz, Mainz, Germany; ${ }^{6}$ Department of Radiology, Johns Hopkins Medical \\ Institutions, Baltimore, MD, USA; 'Department of Psychiatry, Johns Hopkins Medical Institutions, Baltimore, MD, USA
}

\begin{abstract}
Positron emission tomography (PET) studies reveal that clozapine at clinically used doses occupies less than $60 \%$ of $D_{2} / D_{3}$ dopamine receptors in human striatum. Here, the occupancy of $D_{2} / D_{3}$ dopamine receptors by clozapine in patients with schizophrenia was determined to test the hypothesis that clozapine binds preferentially to extrastriatal dopamine receptors. A total of I5 clozapine-treated inpatients with schizophrenia underwent a $\left[{ }^{18} \mathrm{~F}\right]$ fallypride PET scan. Receptor occupancy was calculated as percent reduction in binding potential relative to unblocked values measured in seven normal volunteers. Mean $D_{2} / D_{3}$ receptor occupancy was statistically significantly higher in cortical (inferior temporal cortex 55\%) than in striatal regions (putamen 36\%, caudate 43\%, $p<0.005$ ). While the maximum attainable receptor occupancy $E_{\max }$ approached $100 \%$ both in the striatum and cortex, the plasma concentration at $50 \%$ of $E_{\text {max }}\left(E D_{50}\right)$ was much higher in the putamen $(950 \mathrm{ng} / \mathrm{ml})$ than in the inferior temporal cortex $(333 \mathrm{ng} / \mathrm{ml})$. Clozapine binds preferentially to cortical $D_{2} / D_{3}$ receptors over a wide range of plasma concentrations. This selectivity is lost at extremely high plasma levels. Occupancy of cortical receptors approaches $60 \%$ with plasma clozapine in the range $350-400 \mathrm{ng} / \mathrm{ml}$, which corresponds to the threshold for antipsychotic efficacy of clozapine. Extrastriatal binding of clozapine may be more relevant to its antipsychotic actions than striatal. However, further studies with an intraindividual comparison of untreated vs treated state are desirable to confirm this finding. Neuropsychopharmacology (2006) 3 I, 1027-1035. doi:I0.1038/sj.npp. I 30093 I; published online 12 October 2005
\end{abstract}

Keywords: positron emission tomography; [ $\left.{ }^{18} \mathrm{~F}\right]$ fallypride; clozapine; $\mathrm{D}_{2}$ receptor occupancy; schizophrenia

\section{INTRODUCTION}

Until recently, the occupancy of $\mathrm{D}_{2}$-like dopamine receptors by antipsychotic drugs was determined in striatal structures only. With positron emission tomography (PET) methodology, Farde et al (1992) demonstrated that clinically effective doses of typical neuroleptics occupy $\mathrm{D}_{2}$-like dopamine receptors in the range between 65 and $90 \%$. The suggestion of a 'therapeutic window' between 60 and $80 \%$ striatal $\mathrm{D}_{2}$ receptor occupancy for sufficient treatment response and a

Part of this work was presented at the 42 nd Meeting of the American College of Neuropsychopharmacolgy (ACNP), December 7-II, 2003, San Juan, Puerto Rico

*Correspondence: Dr G Gründer, Department of Psychiatry and Psychotherapy, RWTH Aachen University, Pauwelsstrasse 30, 52074 Aachen, Germany, Tel: +49 24l 80 884I5, Fax: +49 24l 80 33884I5, E-mail: ggruender@ukaachen.de

Received I June 2005; revised 25 August 2005; accepted 2 September 2005

Online publication: 8 September 2005 at http://www.acnp.org/citations/ Npp090805050358/default.pdf 'ceiling' of around $80 \%$ occupancy for extrapyramidal side effects (EPS) was later confirmed by a number of other groups (Kapur et al, 2000a). This rule seems to apply also for most of the 'atypical' antipsychotics (Kapur et al, 1999), but not for partial agonists (Gründer et al, 2003a). Interestingly, the early PET studies with clozapine demonstrated that clozapine occupies striatal $\mathrm{D}_{2}$ receptors to a significantly lesser extent than other antipsychotics, with the exception of quetiapine (Nordström et al, 1995; Kapur et al, 2000b, 1999). It was concluded that the low frequency of EPS observed under treatment with clozapine may be a reflection of the comparatively low $\mathrm{D}_{2}$ receptor occupancy induced by clinical doses of this drug.

With the availability of high-affinity radiotracers belonging to the class of substituted benzamides, it became possible to visualize and quantify extrastriatal dopamine receptors. However, the first studies in drug-treated schizophrenic patients performed with these ligands revealed controversial results with regard to the differential occupancy of striatal $v s$ extrastriatal regions, which has been attributed to tracer characteristics and methodological 
pitfalls. Using $\left[{ }^{123} \mathrm{I}\right]$ epidepride SPECT, Pilowsky et al (1997) demonstrated a higher occupancy of temporal cortical than striatal $D_{2}$ receptors by clozapine. This group reported the same observation for a number of other atypical antipsychotics (Bigliani et al, 2000; Bressan et al, 2003). On the other hand, using $\left[{ }^{11} \mathrm{C}\right] \mathrm{FLB}-457$ PET, the Karolinska group could not detect preferential extrastriatal binding of clozapine (Talvik et al, 2001). However, since striatal occupancy is not reliably quantifiable with $\left[{ }^{11} \mathrm{C}\right] \mathrm{FLB}-457$, they used $\left[{ }^{11} \mathrm{C}\right]$ raclopride for determination of striatal occupancy. Olsson and Farde (2001) suggested that the finding of preferential mesolimbic binding by clozapine is an artifact resulting from underestimation of striatal $\mathrm{D}_{2}$ receptor occupancy. This is in line with the observation that striatal $\mathrm{D}_{2}$ receptor occupancy is markedly underestimated when a high-affinity radiotracer $\left(\left[{ }^{76} \mathrm{Br}\right] \mathrm{FLB}-457\right)$ is used, and striatal and extrastriatal $\mathrm{D}_{2}$ receptor occupancy is determined at the same early time after radiotracer injection (Xiberas et al, 2001; Vernaleken et al, 2004). On the other hand, it has been argued that cortical binding is underestimated with $\left[{ }^{11} \mathrm{C}\right] \mathrm{FLB}-457$ (Erlandsson et al, 2003). Thus, previous methods and study designs were not completely adequate to resolve the uncertainty in determining the $\mathrm{D}_{2} / \mathrm{D}_{3}$ receptor occupancy in striatal $v s$ extrastriatal regions.

Substituted benzamides with a fluorine-18 label have been developed for broader clinical use, because the fluorine- 18 label offers the advantage of a longer half-life compared to the carbon-11 label of, for example, $\left[{ }^{11} \mathrm{C}\right]$ raclopride. Two of the most promising compounds are $\left[{ }^{18} \mathrm{~F}\right]$ fallypride and $\left[{ }^{18} \mathrm{~F}\right]$ desmethoxyfallypride, with $\left[{ }^{18} \mathrm{~F}\right]$ fallypride having a higher affinity for $\mathrm{D}_{2}$-like dopamine receptors $\left(\mathrm{IC}_{50} 0.6 \mathrm{vs}\right.$ $15.0 \mathrm{nM}$ ) (Gründer et al, 2003b; Mukherjee et al, 2001). $\left[{ }^{18} \mathrm{~F}\right]$ fallypride is an ideal tracer for the study of both striatal and extrastriatal receptors in a single PET scan. It has been consistently demonstrated in human studies that a dynamic scan of $180 \mathrm{~min}$ duration allows for establishment of a transient equilibrium both in extrastriatal and striatal brain regions (Mukherjee et al, 2002; Siessmeier et al, 2005). Furthermore, Mukherjee et al (2002) have shown that the test-retest variability in all brain regions is below $10 \%$. Thus, the purpose of this $\left[{ }^{18} \mathrm{~F}\right]$ fallypride PET study was to determine the striatal and extrastriatal $\mathrm{D}_{2} / \mathrm{D}_{3}$ receptor-binding characteristics of the prototypic 'atypical' antipsychotic clozapine in patients with schizophrenia.

\section{PATIENTS AND METHODS}

The study was approved by the local ethics committee in Mainz, Germany, and the German radiation safety authorities. In all, 15 patients suffering from schizophrenia and a control group of seven healthy volunteers were included after giving written informed consent. All PET investigations were performed at the PET Center of the University of Mainz, Germany.

\section{Subjects}

Healthy comparison subjects. The control group consisted of seven male volunteers (23-41 years; mean \pm SD: $32.0 \pm$ 6.9). They were free of any relevant somatic complaint, psychiatric diagnosis, and medication. All control subjects received a physical and mental state examination, blood and urine analysis, electroencephalography, electrocardiography, and cerebral magnetic resonance imaging.

Patients. A total of 15 (10 males and five females) patients (25-47 years; mean \pm SD: $36.0 \pm 7.9$ ) were included. The age of the patients did not significantly differ from that of the normals (Mann-Whitney's $U$-test: $35.5 ; p=0.24$ ). In all, 13 patients were diagnosed with schizophrenia and two with schizoaffective disorder according to DSM-IV. All patients received an ongoing, stable, daily dose of clozapine (100-500 mg/day) according to clinical needs for at least 6 weeks. No patient received any concomitant medication, with the exception of benzodiazepine or zolpidem treatment, respectively, in two patients and lithium treatment in a third. For further patient characteristics, see Table 1.

\section{Radiochemistry}

The $\left[{ }^{18} \mathrm{~F}\right]$ fallypride was synthesized as described for $\left[{ }^{18} \mathrm{~F}\right]$ desmethoxyfallypride (Gründer et al, 2003b). The tosylated precursor ((S)- $N$-[(1-allyl)-2-pyrrolidinyl)-methyl]5-(3-toluenesulfonyloxy-propyl)-2,3-dimethoxybenzamide $(5 \mathrm{mg}, 10 \mu \mathrm{mol})$ was dissolved in $1 \mathrm{ml}$ acetonitrile, treated for $5 \mathrm{~min}$ at $85^{\circ} \mathrm{C}$ with potassium carbonate $(5 \mathrm{mg}, 36 \mu \mathrm{mol})$, and subsequently reacted with $\left[{ }^{18} \mathrm{~F}\right]$ fluoride for $20 \mathrm{~min}$ at $85^{\circ} \mathrm{C}$. $\left[{ }^{18} \mathrm{~F}\right]$ fallypride was isolated using high-performance liquid chromatography (HPLC) and adsorbed on a C18 cartridge, and the product eluted with $1 \mathrm{ml}$ ethanol. The final fraction was diluted with $9 \mathrm{ml}$ of an isotonic sodium chloride solution and sterilized by filtration.

\section{Data Acquisition and Analysis}

Images were acquired on a Siemens ECAT EXACT wholebody PET scanner. Data acquisition comprised of a series of 39 time frames $(3 \times 20 \mathrm{~s}, 3 \times 1,3 \times 2,3 \times 3,21 \times 5,2 \times 8$ and $4 \times 10 \mathrm{~min}$ ) with a total scan duration of $180 \mathrm{~min}$. Following a 15 -min transmission scan, a mean of $220 \pm 43 \mathrm{MBq}$ (mean $\pm \mathrm{SD})\left[{ }^{18} \mathrm{~F}\right]$ fallypride was injected intravenously as a bolus. The specific activity at the time of injection was $101 \pm 113 \mathrm{GBq} / \mu \mathrm{mol}$ (mean $\pm \mathrm{SD})$. The injected mass was $2.2 \pm 2.0 \mu \mathrm{g}($ mean $\pm S D)$. Specific activities did not significantly differ between normal controls and patients treated with clozapine (controls: $112 \pm 114 \mathrm{GBq} / \mu \mathrm{mol}$; patients: $96 \pm 116 \mathrm{GBq} / \mu \mathrm{mol})$. Furthermore, the injected mass was not correlated with the measured binding potentials (BP) in any region, neither in healthy volunteers nor in patients. Thus, it is very unlikely that the radiotracer occupied a significant amount $(>5 \%)$ of receptors in brain regions with low receptor density.

BP were calculated on a voxelwise basis using the Lammertsma Simplified Reference Tissue Model, which is based on a two-tissue compartment model (Gründer et al, 2003b; Lammertsma and Hume, 1996). The cerebellum was chosen as a reference region, since it is generally considered dopamine receptor free. We cannot exclude the possibility that the occupancy values in our study are slightly underestimated due to a very small specific binding in the cerebellum (Mukherjee et al, 2001). Nevertheless, assuming that $\left[{ }^{11} \mathrm{C}\right] \mathrm{FLB}-457$ and $\left[{ }^{18} \mathrm{~F}\right]$ fallypride have similar cerebellar

Neuropsychopharmacology 
Table I Patient Characteristics, Clozapine Plasma Concentrations and Corresponding $D_{2}$-Like Dopamine Receptor Occupancies in Several Brain Regions as Determined with [ ${ }^{18} \mathrm{~F}$ Fallypride PET

\begin{tabular}{|c|c|c|c|c|c|c|c|c|c|c|c|c|}
\hline \multirow[b]{2}{*}{$\begin{array}{l}\text { Patient } \\
\text { no. }\end{array}$} & \multirow[b]{2}{*}{ Age } & \multirow[b]{2}{*}{ Gender } & \multirow[b]{2}{*}{$\begin{array}{l}\text { Clozapine dosing } \\
\text { scheme }(\mathrm{mg})\end{array}$} & \multirow[b]{2}{*}{$\begin{array}{c}\text { Interval (h) } \\
\text { last dose/PET }\end{array}$} & \multicolumn{2}{|c|}{ Plasma conc. ( $\mathrm{ng} / \mathrm{ml})$} & \multicolumn{6}{|c|}{$D_{2} / D_{3}$ receptor occupancy (\%) } \\
\hline & & & & & Morning $^{a}$ & $\mathbf{P E T}^{\mathrm{b}}$ & Putamen & Caudate & $\begin{array}{l}\text { Inf. } \\
\text { temp. }\end{array}$ & Thalamus & Amygdala & S. nigra \\
\hline I & 28 & $\mathrm{~m}$ & $100-0-275-0$ & 8 & 861 & 811 & 55 & 62 & 69 & 63 & 53 & 53 \\
\hline 2 & 25 & $\mathrm{~m}$ & $0-200-0-0$ & 4 & 217 & 816 & 46 & 51 & 65 & 52 & 44 & 56 \\
\hline 3 & 47 & $\mathrm{~m}$ & $0-25-0-200$ & 2 & 362 & 294 & 10 & 19 & 26 & 26 & 3 & 26 \\
\hline 5 & 37 & $\mathrm{~m}$ & $0-50-0-250$ & 0.5 & 378 & 268 & 32 & 38 & 53 & 36 & 47 & 22 \\
\hline 6 & 34 & $f$ & $0-200-0-0$ & 4 & 406 & 498 & 40 & 50 & 26 & 47 & 48 & 28 \\
\hline 7 & 35 & $\mathrm{~m}$ & $0-100-0-0$ & 4 & 890 & 1228 & 42 & 51 & 71 & 42 & 57 & 53 \\
\hline 8 & 47 & $\mathrm{~m}$ & $0-200-0-0$ & 4 & 356 & 694 & 50 & 57 & 80 & 61 & 71 & 60 \\
\hline 9 & 47 & $\mathrm{~m}$ & $100-0-0-0$ & 4 & 694 & 1079 & 51 & 55 & 74 & 57 & 51 & 56 \\
\hline 13 & 25 & $\mathrm{~m}$ & $0-0-250-250$ & 14 & 599 & 657 & 34 & 41 & 40 & 52 & 50 & 34 \\
\hline 14 & 42 & $f$ & $0-0-0-150$ & 16 & 150 & 181 & 0 & 0 & 20 & 5 & 0 & 0 \\
\hline 15 & 26 & $\mathrm{~m}$ & $0-0-75-100$ & 16 & 215 & 246 & 6 & 18 & 27 & 36 & 4 & 23 \\
\hline
\end{tabular}

Clozapine dosing scheme: clozapine was administered at four times: at 0800, 1200, 1800, $2100 \mathrm{~h} . \mathrm{m}=$ male; $\mathrm{f}=$ female; plasma conc. = clozapine plasma concentration. a Determined at $0800 \mathrm{~h}$.

${ }^{b}$ Determined immediately before injection of the radiotracer.

Inf. temp. = inferior temporal cortex; S. nigra = substantia nigra.

binding characteristics, this underestimation should be less than $5 \%$ at the occupancy values that were studied (Olsson et al, 2004). This is a reasonable assumption given the similar structures of the two radioligands (Halldin et al, 1995; Mukherjee et al, 1995). Also, it is unlikely that lipophilic metabolites contribute to the occupancy measures reported in this study. Mukherjee et al (1995) could not detect specific receptor binding, when they extracted the main lipophilic metabolite of $\left[{ }^{18} \mathrm{~F}\right]$ fallypride from blood plasma of humans and incubated it in rat brain slices containing the striata. For determination of $\mathrm{D}_{2}$ receptor occupancy, averaged BPs of control subjects were used as the common baseline value, based on the assumption that there is no difference in $B_{\max }$ between patients and healthy control subjects when measured with benzamide radiotracers (Farde et al, 1987; Hietala et al, 1994). BP images were stereotactically normalized for calculation of $\mathrm{D}_{2} / \mathrm{D}_{3}$ receptor occupancy. First, integrated images (summed images, $3^{\prime}-19^{\prime}$ p.i.) were calculated and spatially normalized using SPM and a ligand-specific $\mathrm{D}_{2}$ template (Buchholz et al, 2004). Transformation parameters of normalization were then applied to the individual BP image.

\section{Calculation of $D_{2} / D_{3}$ Receptor Occupancy}

The individual subject's receptor occupancy was defined as percentage reduction of $\mathrm{BP}$ relative to the baseline $\mathrm{BP}$ according to the following equation:

$$
\text { Occupancy }[\%]=\left(1-\frac{\mathrm{BP}_{\text {Drug }}}{\mathrm{BP}_{\text {Control }}}\right) \times 100
$$

A fixed ROI template was defined to evaluate BP values from individual studies on the stereotactically normalized images comprising the following areas: putamen, caudate nucleus, thalamus, inferior temporal cortex, amygdala, and substantia nigra. The inferior temporal cortex (anterior and medial parts) was used as representative of cortical binding, because the $D_{2} / D_{3}$ receptor density in this region is highest compared to all other cortical regions (illustrated in Figure 3). The use of cortical brain regions with even lower $\mathrm{D}_{2} / \mathrm{D}_{3}$ receptor density such as the prefrontal cortex would have further increased the variability in the binding data (data not shown). A mean $\mathrm{BP}_{\text {Control }}$ value for each ROI was then calculated by averaging $\mathrm{BP}$ values from seven volunteer studies. $\mathrm{BP}_{\text {Drug }}$ was calculated in an equivalent way for the 15 patient studies.

In order to illustrate regional differences in clozapine occupancy in an observer-independent manner, a parametric mean occupancy image was generated (Figure 3) based on the above-mentioned occupancy equation. To decrease noise, voxels with a ratio $\mathrm{BP}_{\text {Drug }} / \mathrm{BP}_{\text {Control }}$ exceeding a threshold $<0.01$ or $>100$, were excluded from calculation (resulting in exclusion of less than $5 \%$ of all voxels, mainly located in areas without relevant specific binding: cerebellum and occipital cortex). The occupancy value of these voxels was set to 0 . Finally, the generated parametric image was smoothed with a Gaussian filter (filter width: $8 \mathrm{~mm}$ ).

\section{Clozapine Pharmacokinetic Data}

Clozapine was usually administered in divided doses. In most cases, the largest portion of the daily dose was 
administered in the evening. In order to induce very high clozapine plasma levels at the time of the PET scan, the total daily dose was administered $3 \mathrm{~h}$ (mean time from administration to $t_{\max }$ ) before tracer injection in some patients. Dosing details for individual patients in relation to tracer injection are given in Table 1. Blood samples were collected at $0800 \mathrm{~h}$ (immediately before ingestion of clozapine, when a morning dose was administered) and again immediately before $\left[{ }^{18} \mathrm{~F}\right]$ fallypride bolus injection. The PET scans were started between 1200 and $1700 \mathrm{~h}$. Clozapine and its demethylated metabolite were determined in serum by a previously published method using HPLC with column switching and quantified by ultraviolet (UV) spectroscopy at $254 \mathrm{~nm}$ (Weigmann et al, 2001). There was linear correlation between drug concentration and UV signal from 100 to at least $1000 \mathrm{ng} / \mathrm{ml}$. The limits of quantification were below $53 \mathrm{ng} / \mathrm{ml}$ for clozapine and $51 \mathrm{ng} / \mathrm{ml}$ for $\mathrm{N}$-desmethylclozapine. At therapeutic concentrations of clozapine, the intra- and inter-assay reproducibility of quality control samples was below $5 \%$.

\section{Statistical Analyses}

Means and standard deviations were calculated for plasma concentrations and occupancy values. Unpaired $t$-tests were used to compare $D_{2} / D_{3} B P$ values for the healthy volunteers and the clozapine-treated patients. A general linear model for repeated measures with within-subjects factor at four levels was applied to compare $D_{2} / D_{3}$ receptor occupancy in four regions evaluated: putamen, caudate nucleus, thalamus, and inferior temporal cortex. Spearman rank correlations were calculated for relationships between clozapine doses and plasma concentrations and brain $\mathrm{D}_{2} / \mathrm{D}_{3}$ receptor occupancy values. Plasma concentrations (trough plasma levels in the morning and at time of injection) and $\mathrm{D}_{2} / \mathrm{D}_{3}$ receptor occupancy values were fit to a one-site ligandbinding model by nonlinear regression analysis using Sigma Plot, Version 8.0, to the following equation:

$$
\text { Occupancy }[\%]=\frac{E_{\max } \times\left[C_{\mathrm{Clz}}\right]}{\mathrm{EC}_{50}+\left[\mathrm{C}_{\mathrm{Clz}}\right]}
$$

where $E_{\max }$ is the maximum attainable receptor occupancy, $\mathrm{EC}_{50}$ is the plasma concentration predicted to provide $50 \%$ of the maximum attainable receptor occupancy and $C_{\mathrm{Clz}}$ is the plasma concentration of clozapine. In all analyses, the two-tailed level of statistical significance was set at $\alpha=0.05$.

\section{RESULTS}

Clozapine-treated patients had statistically significantly lower mean $\mathrm{D}_{2} / \mathrm{D}_{3}$ receptor-BP values than healthy volunteers in the putamen $(13.6 \pm 4.2$, mean $\pm S D$, vs $21.1 \pm 3.7$, respectively; $T=4.1, \mathrm{df}=20, p=0.001)$, caudate nucleus $(11.7 \pm 4.0$ vs $20.5 \pm 3.8 ; T=4.9, \mathrm{df}=20, p<0.001)$, temporal cortex $(0.35 \pm 0.17 v s 0.78 \pm 0.29 ; T=4.5, \mathrm{df}=20, p<0.001)$, thalamus $\quad(1.13 \pm 0.32 \quad v s \quad 2.03 \pm 0.53 ; \quad T=5.0, \quad \mathrm{df}=20$, $p<0.001)$, amygdala $(0.73 \pm 0.31$ vs $1.25 \pm 0.32 ; T=3.6$, $\mathrm{df}=20, p=0.002)$, and substantia nigra $(0.92 \pm 0.35$ vs $1.55 \pm 0.36 ; T=3.9, \mathrm{df}=20, p=0.001)$.

Multivariate tests revealed significant differences in the $D_{2} / D_{3}$ receptor occupancy observed in the four regions examined $(\mathrm{F}=30.0, \mathrm{df}=3.0, p<0.001)$. Post hoc contrasts showed that $D_{2} / D_{3}$ receptor occupancy was significantly lower in striatal regions than in the inferior temporal cortex (Table 2, Figures 1-3). The mean $\mathrm{D}_{2} / \mathrm{D}_{3}$ receptor occupancy in striatal regions was statistically significantly lower than in the inferior temporal cortex (putamen: $\mathrm{F}=33.3, \mathrm{df}=1$, $p<0.001$; caudate: $\mathrm{F}=12.7, \mathrm{df}=1, p=0.003$ ). Occupancy in the caudate nucleus was significantly higher than in the putamen $(\mathrm{F}=78.7, \mathrm{df}=1, p<0.001)$. Similarly, the $\mathrm{D}_{2} / \mathrm{D}_{3}$ receptor occupancy in the thalamus was between those obtained in the putamen $(\mathrm{F}=11.4, \mathrm{df}=1, p=0.004)$ and the inferior temporal cortex $(\mathrm{F}=7.3, \mathrm{df}=1, p=0.017) . \mathrm{D}_{2} / \mathrm{D}_{3}$ receptor occupancy values for the other brain regions are given in Table 2.

The mean clozapine plasma concentration at the time of injection of the radiotracer was $595 \mathrm{ng} / \mathrm{ml}(\mathrm{SD}=335 \mathrm{ng} / \mathrm{ml}$,

Table $2 D_{2} / D_{3}$ Receptor Occupancy (Means $\pm S D$ ), $E_{\max }$, and $E_{50}$ Values (Means \pm SEM) in Selected Brain Regions in 15 Patients with Schizophrenia and Schizoaffective Disorder Receiving Therapeutic Doses of Clozapine

\begin{tabular}{lcrc}
\hline & $\mathbf{D}_{\mathbf{2}} / \mathbf{D}_{\mathbf{3}}$ occupancy (\%) & $\boldsymbol{E}_{\mathbf{m a x}}(\%)$ & $\mathbf{E C}_{\mathbf{5 0}}(\mathbf{n g} / \mathbf{m l})$ \\
\hline Putamen & $36 \pm 5$ & $103 \pm 44$ & $950 \pm 720$ \\
Caudate nucleus & $43 \pm 5$ & $94 \pm 25$ & $582 \pm 337$ \\
Inf. temp. cortex & $55 \pm 6$ & $93 \pm 24$ & $333 \pm 235$ \\
Thalamus & $44 \pm 4$ & $74 \pm 12$ & $324 \pm 151$ \\
Amygdala & $43 \pm 6$ & $96 \pm 39$ & $624 \pm 531$ \\
Substantia nigra & $42 \pm 5$ & $89 \pm 28$ & $572 \pm 392$ \\
\hline
\end{tabular}

$E_{\text {max }}$ is the maximum attainable receptor occupancy and $E_{50}$ is the plasma concentration predicted to provide $50 \%$ of the maximum attainable receptor occupancy.

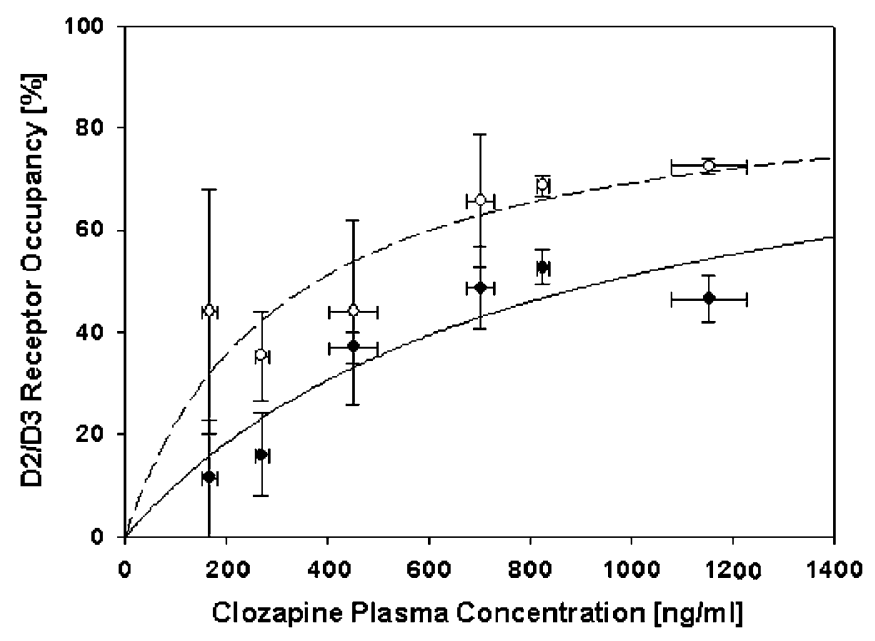

Figure I Relationship between clozapine plasma levels (x-axis) and dopamine $D_{2} / D_{3}$ receptor occupancy in the putamen ( $y$-axis, filled circles, solid line) and in the inferior temporal cortex (open circles, dashed line) in I5 patients with schizophrenia and schizoaffective disorder receiving therapeutic doses of clozapine. For illustrative purposes, plasma concentrations were averaged stepwise (0-199, 200-399, 400-599 ng/ml, etc) and, together with their corresponding occupancy values, presented as means $\pm S E M$. However, statistical values presented in the text are based on individual values. 
range $151-1228 \mathrm{ng} / \mathrm{ml}$ ). Clozapine plasma concentrations determined in the morning were correlated with plasma levels at time of the PET scan on a trend level $\left(r_{\mathrm{s}}=0.58\right.$, $p=0.060)$. The daily clozapine dose was neither significantly correlated with the clozapine plasma concentration $(p=0.099)$ nor with $\mathrm{D}_{2} / \mathrm{D}_{3}$ receptor occupancy in any brain region $(p>0.1)$.

When clozapine plasma concentrations and occupancy values were related to each other according to the law of

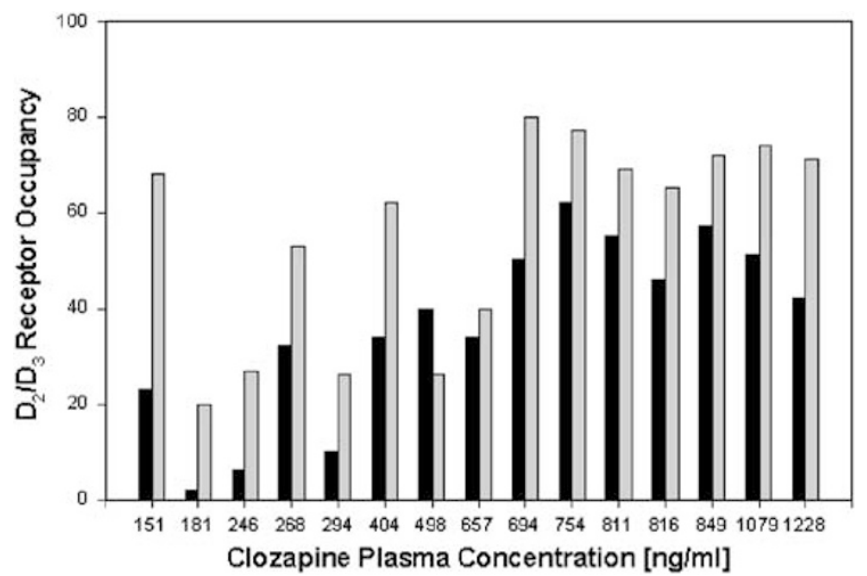

Figure 2 Individual occupancy values in the putamen (black bars) and in the inferior temporal cortex (gray bars) over a wide range of clozapine plasma concentrations determined in 15 patients with schizophrenia and schizoaffective disorder receiving therapeutic doses of clozapine. In 14 out of I 5 patients, temporal cortical occupancy was higher than the occupancy in putamen. The statistical analysis is given in the Results section. mass action (for details, see Patients and methods section, paragraph Statistical analyses), plasma concentrations were significantly positively correlated with $\mathrm{D}_{2} / \mathrm{D}_{3}$ receptor occupancy values for all regions evaluated. Positive correlations were found between clozapine plasma concentrations and occupancy values in the putamen $(r=0.82$, $\mathrm{df}=1, p=0.0002$; Figure 1$)$, the caudate nucleus $(r=0.81$, $\mathrm{df}=1, p=0.0003)$, the inferior temporal cortex $(r=0.58$, $\mathrm{df}=1, p=0.023$; Figure 1$)$, the thalamus $(r=0.80, \mathrm{df}=1$, $p=0.0004)$, the amygdala $(r=0.70, \mathrm{df}=1, p=0.004)$, and the substantia nigra $(r=0.75, \mathrm{df}=1, p=0.001)$. Figure 1 shows the relationship between clozapine plasma concentration and receptor occupancy in the putamen and the inferior temporal cortex. While the occupancy of temporal cortical $\mathrm{D}_{2} / \mathrm{D}_{3}$ dopamine receptors by clozapine is higher over a wide range of plasma concentrations, occupancy values in the putamen approach the cortical values at very high plasma levels, which are usually not achieved in clinical practice. This is further supported by the calculated $E_{\max }$ and $\mathrm{EC}_{50}$ values, which are given in Table 2 . The maximum attainable receptor occupancy was close to complete saturation in all brain regions, with the exception of the thalamus (Table 2). However, the plasma concentrations leading to half-maximal $\mathrm{D}_{2} / \mathrm{D}_{3}$ receptor occupancy were markedly different (Figure 1; Table 2). Interestingly, with an $E_{\max }$ value of just $74 \%(\mathrm{SE}=12 \%)$, the thalamus was the only brain region where $\mathrm{D}_{2} / \mathrm{D}_{3}$ receptors were theoretically not saturable.

When a mean $D_{2} / D_{3}$ receptor occupancy map is generated on a voxel basis, the preferential extrastriatal binding of clozapine in the clinically used dose range becomes even

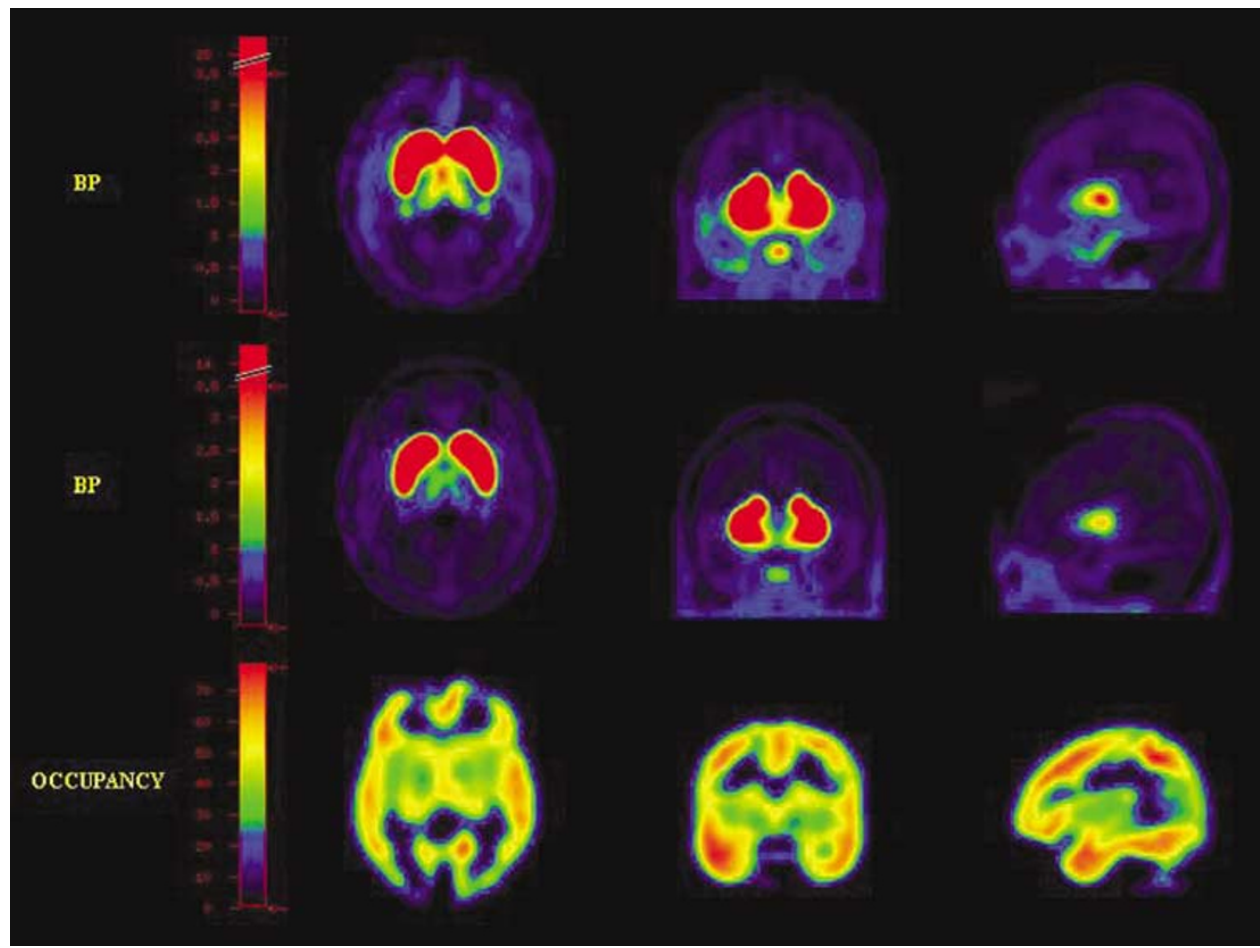

Figure 3 Parametric mean BP images in normal volunteers $(n=7$, top row) and in clozapine-treated patients ( $n=15$, middle row). The bottom row illustrates the $D_{2} / D_{3}$ receptor occupancy in each single voxel in the patient group, clearly demonstrating the significantly higher binding in cortical regions compared to the striatum. 
more apparent (Figure 3), revealing the significantly higher binding in cortical regions compared to the striatum.

\section{DISCUSSION}

In this study, we could demonstrate that clozapine occupies a significantly larger proportion of cortical than striatal $D_{2} /$ $\mathrm{D}_{3}$ receptors over a wide range of plasma levels. Thus, our results are consistent with the finding initially reported by Pilowsky et al (1997). However, this group possibly found a serendipitous finding, because the methodology was not optimal (Olsson and Farde, 2001; Talvik et al, 2001). Since we performed dynamic PET scanning and, in addition, could relate the occupancy values to clozapine plasma levels, more conclusions can be drawn from our study.

Firstly, while both Nordström and Kapur in their $\left[{ }^{11} \mathrm{C}\right]$ raclopride PET studies determined an $E_{\max }$ of approximately $70 \%$ in the striatum, we calculated a maximum attainable receptor occupancy of 94 and $103 \%$ in the caudate nucleus and the putamen, respectively (Kapur et al, 1999; Nordström et al, 1995). Theoretically however, these values are reached at plasma concentrations that are never obtained under clinical conditions in humans (approximately $3300 \mathrm{ng} / \mathrm{ml}$ ). Our findings confirm earlier observations from monkey PET studies that very high intravenous doses are able to occupy striatal $\mathrm{D}_{2}$ receptors almost completely (Mukherjee et al, 2001; Suhara et al, 2002a). At such high doses, the differential occupancy of cortical vs striatal $\mathrm{D}_{2} / \mathrm{D}_{3}$ receptors is lost. The reason why both Nordström et al (1995) and Kapur et al (1999) could not determine $E_{\max }$ values above $70 \%$ could be due to the fact that in their studies a number of patients had high $\mathrm{D}_{2}$ occupancies at relatively low plasma concentrations. Consequently, the curve fits obtained from these data were driven by those few patients.

On the other hand, the half-maximal $\mathrm{D}_{2} / \mathrm{D}_{3}$ receptor occupancy in the temporal cortex was determined to be slightly above $300 \mathrm{ng} / \mathrm{ml}$ in our study. A threshold plasma level for antipsychotic efficacy of clozapine of 350-400 ng/ $\mathrm{ml}$ is now well established (Perry et al, 1991; Kronig et al, 1995), although a few studies found somewhat higher thresholds (Potkin et al, 1994). Thus, our results suggest that clozapine's antipsychotic efficacy could be related to a $\mathrm{D}_{2} / \mathrm{D}_{3}$ receptor occupancy in the temporal cortex of about $60 \%$. Such an occupancy has been initially proposed as the threshold occupancy value for striatal $\mathrm{D}_{2}$-like dopamine receptors, when conventional antipsychotics were studied (Kapur et al, 2000a; Farde et al, 1992). Low-affinity drugs such as clozapine or, more recently, quetiapine, seemed to be exceptions from the classical rule (Farde et al, 1992; Kapur et al, 2000b). This observation led Nordström et al (1995) to state 'that a high $\mathrm{D}_{2}$ receptor occupancy is not an absolute prerequisite for antipsychotic effect'. This might indeed be true for the occupancy of striatal $\mathrm{D}_{2}$ receptors. However, our results suggest that antagonism of cortical $\mathrm{D}_{2}$ receptors seems to be the more general principle for antipsychotic efficacy. The validity of this principle can be easily tested by applying it to other low-affinity antipsychotics, especially quetiapine, where striatal $D_{2}$ binding is low (Kapur et al, 2000b; Gefvert et al, 2001). While there is evidence for a direct relationship between disrupted patterns of $\mathrm{D}_{2}$ dopamine receptors in the temporal cortex in schizophrenia and certain aspects of its psychopathology (Goldsmith et al, 1997), there are numerous actions of antipsychotic drugs on cortical molecular targets that are mediated by antagonism of $\mathrm{D}_{2}$-like dopamine receptors. These actions include downregulation of $\mathrm{D}_{1}$-like dopamine receptors and modification of NMDA receptor expression, among many others (Lidow et al, 1997; Riva et al, 1997). We could not detect statistically significant relationships between binding to $D_{2} / D_{3}$ receptors in any brain region and improvement in psychopathology. Larger sample sizes and different study designs would be needed to find such associations. Interestingly, even some of the patients with relatively low cortical receptor occupancy (below 40\%) were at least partial responders to clozapine treatment. The exact (genetic?) mechanisms that translate receptor occupancy into response in individual patients remain to be elucidated.

Our results are in line with those obtained by Kessler et al (2002), who determined higher extrastriatal $\mathrm{D}_{2}$ binding in a small sample $(n=5)$ of patients treated with clozapine, but not in patients treated with olanzapine or risperidone. However, since plasma levels were not reported by these investigators, the results are somewhat inconclusive. In the same study, it was reported that clozapine occupies significantly less $\mathrm{D}_{2}$ receptors in the substantia nigra than any other drug that was evaluated. These authors suggest that the reduced binding to $\mathrm{D}_{2}$ autoreceptors could explain clozapine's unique clinical properties. We could not confirm this finding in our larger patient sample. Since the substantia nigra is a very small structure, determination of receptor occupancy in this brain region is extremely sensitive to partial volume effects. Therefore, we believe that a partial volume correction of the acquired radioactivity is necessary for determination of dopamine receptor occupancy in the substantia nigra to give a definite answer to the question whether clozapine exerts a reduced binding to dopamine autoreceptors.

In order to obtain occupancy values for a broad range of clozapine plasma levels, we investigated patients on various dosing schedules. However, regardless of the time of the PET scan relative to the last drug administration, the estimated data could be described by a nonlinear fit according to the law of mass action. As long as the occupancy is determined at a range of plasma concentrations, the time of the PET scan relative to the last drug administration is not relevant for illustration of the drug kinetics at the target receptor. The time-course of dopamine $\mathrm{D}_{2}$ receptor occupancy of an antipsychotic is a function of its plasma pharmacokinetics and in vivo affinity (Takano et al, 2004). Thus, compounds with a short half-life and/or a low affinity such as clozapine and quetiapine are described by a flat plasma concentration/occupancy curve, whereas compounds with a long half-life and/or a high affinity such as haloperidol are described by a steep curve. A possible explanation for these regionally varying dose occupancy curves might be the following: $\mathrm{D}_{2}$ receptor occupancies observed under antipsychotics with moderate or low affinity might be influenced by endogenous dopamine (Seeman, 2002). Dopamine concentrations in animal striatum are significantly higher compared to cortical concentrations when measured with tissue homogenate or microdialysis techniques (Brown et al, 1979; Pehek, 1999). Furthermore, 
there are markedly different kinetics of dopamine release and reuptake across brain regions (Garris and Wightman, 1994). These differences in competition of clozapine against endogenous dopamine could contribute to the abovementioned regional differences of concentration/occupancy curves. Additionally, upregulation of $\mathrm{D}_{2}$ but not $\mathrm{D}_{3}$ receptors under antipsychotic treatment together with different spatial distributions of $\mathrm{D}_{2}$ and $\mathrm{D}_{3}$ receptors may contribute to the described observations (Joyce, 2001).

To explain the finding that $\mathrm{D}_{2} / \mathrm{D}_{3}$ receptor binding was not saturable in the thalamus is more challenging. Several independent groups have reported that $\mathrm{D}_{2}$ receptor availability is reduced in the thalamus in patients with schizophrenia (Talvik et al, 2001; Yasuno et al, 2004). Calculation of receptor occupancy for a brain region with reduced receptor numbers from a comparison with normal volunteers should lead to overestimation of the occupancy, not underestimation. However, if $\mathrm{D}_{2}$ and $\mathrm{D}_{3}$ receptors are differentially regulated by clozapine in selected brain regions, or if $D_{2}$ and $D_{3}$ receptors are differentially regulated in patients with schizophrenia and normal controls, then the estimation of occupancy values in patients from comparison with normative values obtained in healthy subjects might be misleading (Gurevich et al, 1997; Joyce, 2001).

The same might of course be true with regard to temporal cortical binding. Tuppurainen et al (2003), using epidepride SPECT, have recently reported on significantly reduced $D_{2}$ receptor availability in the temporal cortex of seven patients with schizophrenia. If there is indeed a reduced temporal cortical $\mathrm{D}_{2}$ receptor density in schizophrenia, this would produce spuriously high levels of dopamine $\mathrm{D}_{2} / \mathrm{D}_{3}$ receptor occupancy in patients with schizophrenia when using normal volunteers as control subjects. However, both Suhara et al (2002b) and Talvik et al (2003), using PET with $\left[{ }^{11} \mathrm{C}\right] \mathrm{FLB}-457$, failed to find significant reductions in temporal cortical $\mathrm{D}_{2}$ receptor availability in larger samples of 11 and nine patients, respectively. Furthermore, with the exception of the thalamus, we demonstrated a higher extrastriatal than striatal occupancy not only in the temporal cortex but also throughout the brain. Thus, it is unlikely that reduced temporal cortical $\mathrm{D}_{2}$ receptor density in schizophrenia consistently biased our results. However, the low $\mathrm{D}_{2}$ receptor density in the cortex in conjunction with the use of a normal control group for the baseline condition contributes to the comparatively high variability in our data for these regions. Nevertheless, Mukherjee et al (2002) found a test-retest variability of less than $10 \%$ both for striatal and temporal cortical regions, supporting the view that $D_{2}$ receptors can be reliably quantified with $\left[{ }^{18} \mathrm{~F}\right]$ fallypride even in brain regions with a low $\mathrm{D}_{2}$ density (Mukherjee et al, 2002).

In conclusion, we could demonstrate that clozapine occupies a significantly larger proportion of cortical compared to striatal $\mathrm{D}_{2} / \mathrm{D}_{3}$ dopamine receptors over a broad range of plasma levels, and that clinically effective plasma concentrations are related to a temporal cortical $\mathrm{D}_{2} / \mathrm{D}_{3}$ receptor occupancy above approximately $60 \%$. Thus, our study with the largest sample to date suggests that the cerebral cortex rather than the striatum could be the target structure for the evaluation of antipsychotics with PET.

\section{ACKNOWLEDGEMENTS}

We thank Sabine Höhnemann and Markus Piel for performing the syntheses of $\left[{ }^{18} \mathrm{~F}\right]$ fallypride, and Heike Armbrust for assistance in performing the PET studies. We gratefully acknowledge Martina Klein's and Carsten Eulitz' statistical advice. Parts of this work are included in Jasmin Ondracek's doctoral thesis at the Medical Faculty of the University of Mainz. This study was supported by the University of Mainz (MAIFOR program), the Research Fund of the University of Mainz, the State Rheinland-Pfalz, and the German Research Council (DFG, grant Ba 1101/2-1).

\section{FINANCIAL DISCLOSURE}

Dr Gründer has served as a consultant for Bristol-Myers Squibb (New York, NY), Otsuka (Rockville, MD), Pfizer (New York, NY), and Astra Zeneca (London, UK). He has served on the speakers' bureau of Bristol-Myers Squibb, Otsuka, Pfizer, Astra Zeneca, and Eli Lilly (Indianapolis, IN). He has received grant support from Bristol-Myers Squibb, Pfizer, and Sanofi Synthélabo (Paris, France). Dr Wong has served as a consultant for Bristol-Myers Squibb, Lilly and Abbott Labs (Chicago, IL). He has received grant support from Aventis (Strasbourg, France), Janssen (Beerse, Belgium), Eli Lilly, Pfizer, and Sumitomo (Osaka, Japan).

\section{REFERENCES}

Bigliani V, Mulligan RS, Acton PD, Ohlsen RI, Pike VW, Ell PJ et al (2000). Striatal and temporal cortical D2/D3 receptor occupancy by olanzapine and sertindole in vivo: a [123I] epidepride single photon emission tomography (SPET) study. Psychopharmacology 150: 132-140.

Bressan RA, Erlandsson K, Jones HM, Mulligan RS, Ell PJ, Pilowsky LS (2003). Optimizing limbic selective D2/D3 receptor occupancy by risperidone: a [123I]-epidepride SPET study. J Clin Psychopharmacol 23: 5-14.

Brown RM, Crane AM, Goldman PS (1979). Regional distribution of monoamines in the cerebral cortex and subcortical structures of the rhesus monkey: concentrations and in vivo synthesis rates. Brain Res 168: 133-150.

Buchholz H-G, Siessmeier T, Landvogt C, Vernaleken I, Schirrmacher R, Schreckenberger M et al (2004). Stereotactic normalisation of BP images of D2-receptor ligand $18 \mathrm{~F}$ desmethoxyfallypride using ligand-specific template and SPM. Neuroimage 22(Suppl 2): T105.

Erlandsson K, Bressan RA, Mulligan RS, Ell PJ, Cunningham VJ, Pilowsky LS (2003). Analysis of D2 dopamine receptor occupancy with quantitative SPET using the high-affinity ligand [123I]epidepride: resolving conflicting findings. Neuroimage 19: 1205-1214.

Farde L, Nordström AL, Wiesel FA, Pauli S, Halldin C, Sedvall G (1992). Positron emission tomographic analysis of central D1 and D2 dopamine receptor occupancy in patients treated with classical neuroleptics and clozapine. Relation to extrapyramidal side effects. Arch Gen Psychiatry 49: 538-544.

Farde L, Wiesel FA, Hall H, Halldin C, Stone-Elander S, Sedvall G (1987). No $D_{2}$ receptor increase in PET study of schizophrenia (letter). Arch Gen Psychiatry 44: 671-672.

Garris PA, Wightman RM (1994). Different kinetics govern dopaminergic transmission in the amygdala, prefrontal cortex, and striatum: an in vivo voltammetric study. J Neurosci 14: $442-450$. 
Gefvert O, Lundberg T, Wieselgren IM, Bergstrom M, Langstrom $\mathrm{B}$, Wiesel $\mathrm{F}$ et al (2001). $\mathrm{D}(2)$ and $5 \mathrm{HT}(2 \mathrm{~A})$ receptor occupancy of different doses of quetiapine in schizophrenia: a PET study. Eur Neuropsychopharmacol 11: 105-110.

Goldsmith SK, Shapiro RM, Joyce JN (1997). Disrupted pattern of D2 dopamine receptors in the temporal lobe in schizophrenia. A postmortem study. Arch Gen Psychiatry 54: 649-658.

Gründer G, Carlsson A, Wong DF (2003a). Mechanism of new antipsychotic medications: occupancy is not just antagonism. Arch Gen Psychiatry 60: 974-977.

Gründer G, Siessmeier T, Piel M, Vernaleken I, Buchholz H-G, Zhou Y et al (2003b). Quantification of D2-like dopamine receptors in the human brain with $\left[{ }^{18} \mathrm{~F}\right]$ desmethoxyfallypride. J Nucl Med 44: 109-116.

Gurevich EV, Bordelon Y, Shapiro RM, Arnold SE, Gur RE, Joyce JN (1997). Mesolimbic dopamine D3 receptors and use of antipsychotics in patients with schizophrenia. A postmortem study. Arch Gen Psychiatry 54: 225-232.

Halldin C, Farde L, Hogberg T, Mohell N, Hall H, Suhara T et al (1995). Carbon-11-FLB 457: a radioligand for extrastriatal D2 dopamine receptors. J Nucl Med 36: 1275-1281.

Hietala J, Syvalahti E, Vuorio K, Nagren K, Lehikoinen P, Ruotsalainen U et al (1994). Striatal D2 dopamine receptor characteristics in neuroleptic-naive schizophrenic patients studied with positron emission tomography. Arch Gen Psychiatry 51: 116-123.

Joyce JN (2001). D2 but not D3 receptors are elevated after 9 or 11 months chronic haloperidol treatment: influence of withdrawal period. Synapse 40: 137-144.

Kapur S, Zipursky R, Jones C, Remington G, Houle S (2000a). Relationship between dopamine $\mathrm{D}(2)$ occupancy, clinical response, and side effects: a double-blind PET study of first-episode schizophrenia. Am J Psychiatry 157: 514-520.

Kapur S, Zipursky R, Jones C, Shammi CS, Remington G, Seeman P (2000b). A positron emission tomography study of quetiapine in schizophrenia: a preliminary finding of an antipsychotic effect with only transiently high dopamine D2 receptor occupancy. Arch Gen Psychiatry 57: 553-559.

Kapur S, Zipursky RB, Remington G (1999). Clinical and theoretical implications of 5-HT2 and D2 receptor occupancy of clozapine, risperidone, and olanzapine in schizophrenia. Am J Psychiatry 156: 286-293.

Kessler RM, Ansari SM, Li R, Dawant B, Lee M, Meltzer HY (2002). Occupancy of striatal and extrastriatal dopamine D2 receptors by atypical antipsychotic drugs. J Nucl Med 43(Suppl): 15 .

Kronig MH, Munne RA, Szymanski S, Safferman AZ, Pollack S, Cooper $\mathrm{T}$ et al (1995). Plasma clozapine levels and clinical response for treatment-refractory schizophrenic patients. Am J Psychiatry 152: 179-182.

Lammertsma AA, Hume SP (1996). Simplified reference tissue model for PET receptor studies. Neuroimage 4: 153-158.

Lidow MS, Elsworth JD, Goldman-Rakic PS (1997). Downregulation of the D1 and D5 dopamine receptors in the primate prefrontal cortex by chronic treatment with antipsychotic drugs. J Pharmacol Exp Ther 281: 597-603.

Mukherjee J, Christian BT, Dunigan KA, Shi B, Narayanan TK, Satter M et al (2002). Brain imaging of $18 \mathrm{~F}$-fallypride in normal volunteers: blood analysis, distribution, test-retest studies, and preliminary assessment of sensitivity to aging effects on dopamine D-2/D-3 receptors. Synapse 46: 170-188.

Mukherjee J, Christian BT, Narayanan TK, Shi B, Mantil J (2001). Evaluation of dopamine D-2 receptor occupancy by clozapine, risperidone, and haloperidol in vivo in the rodent and nonhuman primate brain using 18F-fallypride. Neuropsychopharmacology 25: 476-488.

Mukherjee J, Yang ZY, Das MK, Brown T (1995). Fluorinated benzamide neuroleptics - III. Development of (S)- $\mathrm{N}$-[(1-allyl-2pyrrolidinyl)methyl]-5-(3-[18F]fluoropropyl)-2, 3-dimethoxy- benzamide as an improved dopamine D-2 receptor tracer. $\mathrm{Nucl}$ Med Biol 22: 283-296.

Nordström AL, Farde L, Nyberg S, Karlsson P, Halldin C, Sedvall G (1995). D1, D2, and 5-HT2 receptor occupancy in relation to clozapine serum concentration: a PET study of schizophrenic patients. Am J Psychiatry 152: 1444-1449.

Olsson H, Farde L (2001). Potentials and pitfalls using high affinity radioligands in PET and SPET determinations on regional drug induced D2 receptor occupancy - a simulation study based on experimental data. Neuroimage 14: 936-945.

Olsson H, Halldin C, Farde L (2004). Differentiation of extrastriatal dopamine D2 receptor density and affinity in the human brain using PET. Neuroimage 22: 794-803.

Pehek EA (1999). Comparison of effects of haloperidol administration on amphetamine-stimulated dopamine release in the rat medial prefrontal cortex and dorsal striatum. J Pharmacol Exp Ther 289: 14-23.

Perry PJ, Miller DD, Arndt SV, Cadoret RJ (1991). Clozapine and norclozapine plasma concentrations and clinical response of treatment-refractory schizophrenic patients. Am J Psychiatry 148: 231-235.

Pilowsky LS, Mulligan RS, Acton PD, Ell PJ, Costa DC, Kerwin RW (1997). Limbic selectivity of clozapine. Lancet 350: 490-491.

Potkin SG, Bera R, Gulasekaram B, Costa J, Hayes S, Jin Y et al (1994). Plasma clozapine concentrations predict clinical response in treatment-resistant schizophrenia. J Clin Psychiatry 55(Suppl B): 133-136.

Riva MA, Tascedda F, Lovati E, Racagni G (1997). Regulation of NMDA receptor subunit messenger RNA levels in the rat brain following acute and chronic exposure to antipsychotic drugs. Brain Res Mol Brain Res 50: 136-142.

Seeman P (2002). Atypical antipsychotics: mechanism of action. Can J Psychiatry 47: 27-38.

Siessmeier T, Zhou Y, Buchholz H-G, Landvogt C, Vernaleken I, Piel $\mathrm{M}$ et al (2005). Comparison of parametric methods for the analysis of PET studies with D2 receptor ligands of different affinities. J Nucl Med 46: 964-972.

Suhara T, Okauchi T, Sudo Y, Takano A, Kawabe K, Maeda J et al (2002a). Clozapine can induce high dopamine $\mathrm{D}(2)$ receptor occupancy in vivo. Psychopharmacology (Berl) 160: 107-112.

Suhara T, Okubo Y, Yasuno F, Sudo Y, Inoue M, Ichimiya T et al (2002b). Decreased dopamine D2 receptor binding in the anterior cingulate cortex in schizophrenia. Arch Gen Psychiatry 59: 25-30.

Takano A, Suhara T, Ikoma Y, Yasuno F, Maeda J, Ichimiya T et al (2004). Estimation of the time-course of dopamine D2 receptor occupancy in living human brain from plasma pharmacokinetics of antipsychotics. Int J Neuropsychopharmacol 7: 19-26.

Talvik M, Nordström AL, Nyberg S, Olsson H, Halldin C, Farde L (2001). No support for regional selectivity in clozapine-treated patients: a PET study with [(11)C]raclopride and [(11)C]FLB 457. Am J Psychiatry 158: 926-930.

Talvik M, Nordstrom AL, Olsson H, Halldin C, Farde L (2003). Decreased thalamic D2/D3 receptor binding in drug-naive patients with schizophrenia: a PET study with [11C]FLB 457. Int J Neuropsychopharmacol 6: 361-370.

Tuppurainen H, Kuikka J, Viinamaki H, Husso-Saastamoinen M, Bergstrom K, Tiihonen J (2003). Extrastriatal dopamine D 2/3 receptor density and distribution in drug-naive schizophrenic patients. Mol Psychiatry 8: 453-455.

Vernaleken I, Siessmeier T, Buchholz H-G, Härtter S, Hiemke C, Stoeter P et al (2004). High striatal occupancy of D2-like dopamine receptors by amisulpride in brain of patients with schizophrenia. Int J Neuropsychopharmacol 7: 421-430.

Weigmann H, Härtter S, Mehrlein S, Kiefer W, Krämer G, Dannhardt G et al (2001). Simultaneous determination of 
olanzapine, clozapine and demethylated metabolites in serum by on-line column-switching high performance liquid chromatography. J Chromatogr B Sci 759: 63-71.

Xiberas X, Martinot JL, Mallet L, Artiges E, Canal M, Loc'h C et al (2001). In vivo extrastriatal and striatal D2 dopamine receptor blockade by amisulpride in schizophrenia. J Clin Psychopharmacol 21: 207-214.

Yasuno F, Suhara T, Okubo Y, Sudo Y, Inoue M, Ichimiya T et al (2004). Low dopamine $d(2)$ receptor binding in subregions of the thalamus in schizophrenia. Am J Psychiatry 161: 1016-1022. 